\title{
J. E. Tatengkeng and Robert Frost's Poems: An Application of Michael Riffaterre's Semiotic Model
}

\author{
Karmila Mokoginta ${ }^{1}$, Nur IImi $^{2}$, Hartina Mahardhika ${ }^{3}$ \\ 1) English Literature Study Program, Faculty of Cultural Sciences, Universitas Hasanuddin \\ ${ }^{2)}$ Secretarial Study Program, Academy of Secretary and Management Atmajaya Makassar \\ 3) Universitas Hasanuddin \\ ${ }^{1)}$ karmila.mokoginta@unhas.ac.id \\ ${ }^{2)}$ nurilmirauf@gmail.com \\ 3) anahartina@gmail.com
}

\begin{abstract}
This paper describes the results of poem analysis using the semiotic model of Riffaterre. The objects of analysis were poems written by J.E Tatengkeng from Indonesia including Di Lereng Gunung, Bulan Terang, and Melati; and Robert Frost from America including Nothing Gold Can Stay, Fireflies in the Garden, and After Apple Picking. The analysis was conducted using two steps of reading. The first was the heuristic reading conducted by using linguistic knowledge; while the second was the retroactive reading conducted by using knowledge beyond the text. This second step was intended to conclude the hypograms, and based on the hypograms, matrices and significance of the poems were concluded. The analysis revealed the poems' matrices and significance related to the value of love, beauty of nature, and religious belief.
\end{abstract}

Keywords: Riffaterre, J.E. Tatengkeng, Robert Frost.

\section{INTRODUCTION}

Poem is a type of literary work that is very distinctive. Its sentences often cannot be interpreted only based on the literal meaning of the words in it. Therefore, the meaning of a poem cannot be understood only by relying on ordinary language analysis. Poems have almost 99\% implicit meaning, so the most appropriate way to interpret poem is to use the semiotic approach. Words are not seen as mere words, but as semiotic signs that does not only represent a fact, but also the meaning outside the fact.

Related to the semiotic approach in literature (including poem), Zoest (1990:3) says that a text is considered as a sign formed by a number of other signs. The expert explains further that the sign in the form of text comes to the readers who then make interpretations of the sign to form a new sign termed in Semiotics as an interpretant. 
This explanation has similarities with the Semiotic model of Peirce. Peirce \& In Buchler (1955:99) provide the following explanation:

"A sign, or representamen, is something which stands to somebody for something in some respect or capacity. It addresses somebody, that is, creates in the mind of that person an equivalent sign, or perhaps a more developed sign. That sign which it creates I call the interpretant of the first sign. The sign stands for something, its object. It stands for that object, not in all respects, but in reference to a sort of idea, which I have sometimes called the ground of the representamen. "Idea" is here to be understood in a sort of Platonic sense, very familiar in everyday talk; I mean in that sense in which we say that one man catches another man's idea, in which we say that when a man recalls what he was thinking of at some previous time, he recalls the same idea, and in which when a man continues to think anything, say for a tenth of a second, in so far as the thought continues to agree with itself during that time, that is to have a like content, it is the same idea, and is not at each instant of the interval a new idea"

Based on the explanation of the experts above, it can be said that the text of a poem is not a single sign, but rather a form of construction of signs that represent something else (denotatum) both existing in the real world and in the form of new signs. Denotatum in reality is relatively easy to find as long as a reader has sufficient understanding of the language used in a poem; whereas interpretation as well as new sign construction or interpretant requires special reading skills. The question is how the process of reading can be done so that the meaning of a poem can be concluded? One of the alternative answers to this can be found in the theory of poem semiotics by Michael Riffaterre. Riffaterre's semiotics that emphasizes a specific method of interpretation, that is by producing the meaning of signs, makes it appropriate to be used in analyzing a poem (Ratih, 2016:5). Riffaterre's theory is also explained in Bahador and Lashkarian (2014:118 121) and Lantowa et al. (2017:8-20). The following is a short explanation based on the two sources.

Text of a poem that is considered as a sign reaches the reader. When reading the text, the reader will read using language knowledge. This reading process is called heuristic reading. From this heuristic reading process, because what is read is a literary text, it is almost certain that the reader will find a number of language discrepancies (ungrammaticalities) in three forms: shifting of meaning (metaphor and metonymy), meaning deviation (ambiguity, contradiction, and meaninglessness), and the creation of meaning (symmetry, homology, and typography). This mismatch does not allow the reader to continue to make the mimetic process, and must move to the process of semiosis through a retroactive reading process using literary competence. In using this literary ability, a reader should have knowledge of descriptive systems, various themes, mythology, and other texts. This knowledge will help the reader to find 
out the real meaning of the text, i.e., what the text says, which is termed a hypogram. It is a statement, or even a text, concluded by the reader (not stated by the author of the literary work). The hypogram is divided into two types, potential hypogram and actual hypogram. Potential hypogram consists of presuppositions, descriptive systems, core meaning, and connotations; whereas the actual hypogram is in the form of another text that is universal and systematic. Based on the concluded hypogram, the reader finds a matrix that is at the core of the text in the form of a minimum word or sentence. This matrix will be a guide for the reader in discovering the significance of a poem; which is an important thing discussed in the poem implicitly, but will emerge explicitly through a retroactive reading (Riffaterre in Lantowa et al., 2017:9). This explanation is summarized in the following diagram.

Diagram of Michael Riffaterre's Semiotic Theory (Summarized based on Bahador dan Lashkarian (2014:118-121) and Lantowa et al. (2017:8-20)

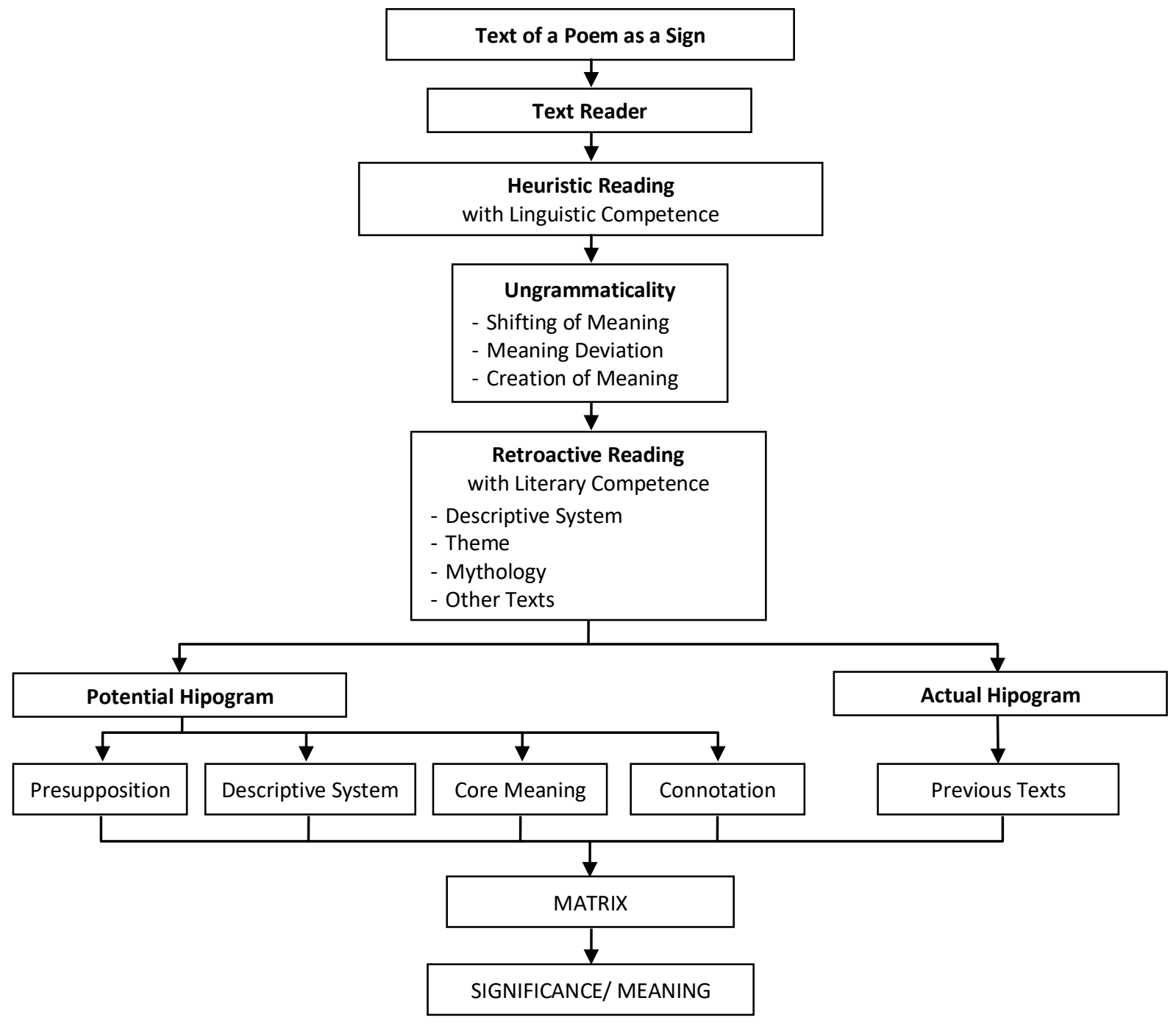


Review of literature reveals that the Semiotic theory of Riffaterre has been used widely in the analysis of literary works, including in Indonesia. Adudu and Husain (2019) wrote an article entitled Semiotic Analysis in William Blake Poems. Based on the analysis, the authors were able to find the meaning of the poem. They claimed that William Blake's My Pretty Rose Tree contains the emotional expression of the poet to his wife; while the two other poems, The Sick Rose and The Garden of Love, contain descriptions of life prior to the French Revolution. Another writing entitled Unveil the Meaning of Ibn Al-Farid's Sufistic Poetry by Choirini and Nursida (2020) also applied the Semiotics theory of Riffaterre. The analysis revealed that many possible interpretations can be obtained from the poems because they contain language expressions that are full of implied meaning. Ibn Al-Farid, according to the authors, "created infinite horizons through the words which bind Sufistic concepts and perceptions" (Choirini and Nursida, 2020:248). Furthermore, Setiawan et al. (2017) analyzed a Kekean poem written by F. Aziz Manna using Riffaterre's theory to find out some meanings related to good human characters. They found that the poem contains such meanings including belief in God, self-appreciation, spirit of working and learning, responsibility, and self-control. Meanwhile, Sipahutar and Arianto (2019) chose Walt Whitman's poems as the objects of analysis using the Riffaterre theory. The results of the analysis showed that "the dominant point in Walt Whitman poems is the unsustainability of expression in poetry" (Sipahutar and Arianto, 2019:237). In addition, Sugiyo and Nurmila (2020) applied Riffaterre's theory in analyzing anxiety in five poems written by Joko Pinurbo; while Viensen (2020) used the theory to analyze three poems by John Milton. These works are just some examples among many studies conducted by Indonesian scholars using Riffaterre's Semiotic theory.

It can be seen in the studies above that many Indonesian scholars have conducted analysis on poems written by either poet of Indonesian or those of other nationalities. A further effort to conduct a comparative analysis is needed to broaden perspectives about the application of Riffaterre's Semiotic model. In this paper, the writers describe the analysis of the poems written by an Indonesian poet, J.E Tatengkeng and an American poet, Robert Frost using the Riffaterre model. In Indonesian literature periods, J. E Tatengkeng is considered a poet of the Punjangga Baru (New Poets) period. According to Pradopo (2007:24-25), this period was dominated by poems, and one of the characteristics of the aesthetic structure was the romantic expression, indicated by expression of feeling, description of the beauty of nature, peace, and other similar things. As part of the Pujangga Baru period, it can be assumed that J. E Tatengkeng was in the same period as Robert Frost; so, analysis of poems of the two poets may lead to comparable results of poetic values. Three of J.E. Tatengkeng poems that were analyzed are: Di Lereng Gunung, Bulan Terang, and Melati; while Robert Frost's poems that 
were analyzed are Nothing Gold Can Stay, Fireflies in the Garden, and After Apple Picking.

\section{METHOD}

The method used in analyzing the poems was based on the Semiotic model of Riffaterre explained above. The analysis was started with a heuristic reading conducted by using linguistic knowledge. The next step was a retroactive reading in which the writers referred to a broader knowledge beyond the text, including knowledge about texts other than the one being analyzed. This second step was intended to conclude the hypogram. Based on the hypograms, matrices and significance of the poems were concluded.

\section{FINDINGS AND DISCUSSIONS}

\section{Analysis of J.E. Tatengkeng's Di Lereng Gunung}

\section{Di Lereng Gunung}

Di lereng gunung,

Aku termenung,

Duduk di sisi,

Kekasih hati.

Kami berpandangan sejurus lama,

Dan mengerti bisikan sukma

Dada yang berdebar

Terang menggambar

Keadaan hati,

Sesudah menanti,

Sekian lama akan waktu,

Dimana jiwa kami bersatu...

O, Hidup! Betapa Indah

Kalau kasih ta'diperintah

Hanya dengan sendiri

Itu datang memberi!

(Tatengkeng, 1974)

\section{- Heuristic Reading}

The above poem is entitled Di Lereng Gunung which literally means a sloping land on a mountain. The title is found on the first line which becomes a background setting of an event in which "Aku" (I), first person singular (either a man or a woman) is being pensive. The third and fourth lines, "Duduk di sisi" (sitting beside) and "Kekasih hati" (sweetheart) respectively, explains that the "I" is sitting not alone on the slopes of the mountain, but with his/her sweetheart. The word "di sisi" means that they both sit side by side.

In the second stanza, the word "berpandangan" (look at each other) in the line "Kami berpandangan sejurus lama" means that there are two people who look at each other for a long time. Next, in the word "Bisikan sukma" (soul whisper) in the line "Dan mengerti bisikan sukma" (And understand the soul whisper) illustrates that the couple look at each other, but they do not talk as if they have understood each other's feeling.

In the third stanza the word "Berdebar" (beat fast) on the line "Dada yang berdebar" (heart that beats fast) indicates that there is a trigger. It is explained in the next lines "Terang menggambar/Keadaan hati / Sesudah menanti /Sekian lama akan waktu /Dimana jiwa kami bersatu" (Clearly show /Heart condition /After waiting /for a long time /When our hearts are united). 
Overall, this stanza explains the heart condition of the character "I" who has been holding back longing and waiting for her lover for a long time to meet again.

In the last stanza of the poem, there is an exclamation point in the first line " $O$, Hidup ! Betapa Indah" (O. Life! Very Beautiful). An exclamation mark in that line shows an affirmation. Furthermore, the word "ta'diperintah" in the line "Kalau kasih ta'diperintah" means without orders or voluntarily. This stanza describes the affirmation of the "I" character that life will be very beautiful if the feeling of love grows by itself without coercion.

Heuristic reading on the poem Di Lereng Gunung above only produces the meaning of the poem based on language conventions. To get a literary convention in the poem, the writers made hermeneutical or retroactive reading explained below.

\section{- Retroactive Reading}

The title of the poem Di Lereng Gunung when viewed from the aspect of the meaning surely will raise questions for the reader. Why should it be on the slopes of a mountain? Why is it not at the top of the mountain where people can admire the beauty of the scenery underneath; or at the foot of the mountain where people can admire the beauty and the strength of the towering mountain. Slopes of a mountain are located between the foot and the top of the mountain where one can admire the whole beauty of both the top and the foot of the mountain. Such a position in the middle, a stable one, implies an impression of reasonableness, something that is balanced.

Overall, the retroactive reading of the poem Di Lereng Gunung is as follows. In the first stanza, there is the character of "I" who is being pensive while sitting on the side of his lover on the mountain slope. Next, in the second stanza, these lovers look at each other and understand each other even if they do not say anything. In the third stanza, the mood is pounding when meeting after a long time apart. In the last stanza there is an affirmation of the "I" character about the beauty of love that grows without coercion.

The model in the poem Di Lereng Gunung is "Kasih" (affection) or "Cinta" (love) because all actions of the "I" character are manifestations of his/her love to someone. The "Kasih" model is expanded into some variants in all poems, namely (1) "mengerti bisikan sukma" (understanding soul whispers); (2) "dada yang debar" (heart that beats fast); and (3) "kasih ta'diperintah" (affection without coercion). The first variant is a description of what is felt by people who have affection or love in themselves. This is what is felt by the "I" character and his/her lover who are sitting and looking at each other. Without saying a word, they have understood each other's hearts. It seems like two people falling in love, without being spoken, as love can still be felt even through the eyes. The second variant is a description 
of the body's natural reaction felt by people who are falling in love. This is felt by the "I" character when he/she meets his/her lover after being separated for a long time. The third variant describes the exclamation or affirmation of the "I" character about the most beautiful form of feelings of affection or love, namely unconditional love that grows without coercion.

After the models and variants are known, the analysis is continued with the determination of the matrix or the center of meaning. The matrix in the poem Di Lereng Gunung is the beauty of love. The matrix leads to a significance that the beauty of love can be felt voluntarily without coercion; and like nature (mountain slopes), the beauty will be maintained if managed fairly and balanced.

\section{Analysis of J.E. Tatengkeng's Bulan Terang}

\section{Bulan Terang}

Sunyi lengang alam terbentang, Udara jernih tenang

Di langit mengerlip ribuan bintang, Bulan memancar caya senang

Angin mengembus tertahan-tahan, Dan berbisik rasa kesukaan.

\section{Bulan beralih perlahan-Iahan} Menuju magrib tempat peraduan.

Hati yang masygul menjadi senang, Sukma riang terbang melayang, Karna lahir Kerinduan semalam: Ribaan Hua yang kukenang, Kudapat t'rang, kasih dan sayang, Serta damai hati di dalam.

(Tatengkeng, 1974)

\section{- Heuristic Reading}

The title of Bulan Terang poem means the moon that shines brightly. Moon is a celestial body that surrounds the earth, glowing at night because of the reflection of the sun. The light of a bright moon can be seen at night, so the time in this poem occurs at night.

The first line "Sunyi lengang alam terbentang" (quite natural atmosphere) shows the situation in a lonely night. "Udara jernih" in the second line "Udara jernih tenang" can be interpreted as clean air without pollution that is often found in rural areas.

The third and fourth lines, "Di langit mengerlip ribuan bintang" and "Bulan memancar caya senang" show the atmosphere of a bright night because the star flicker and moonlight are clearly visible.

The fifth line is "Angin mengembus tertahan-tahan". The word "tertahan-tahan" shows that something does not happen continuously. The line means that the wind that night blows steadily. The sixth line is coherent with the fifth line. The figurative expression "berbisik" (whispering) in the line "Dan berbisik rasa kesukaan" shows a slow hissing voice. So, the sixth line can be interpreted as wind that blows slowly so that it brings coolness.

The seventh and eighth lines are "Bulan beralih perlahan-lahan" (The moon moves slowly) and "Menuju magrib tempat 
peraduan" (Going to magrib the place of rest) respectively. The word "beralih" means to move. Something that moves is sure to go to another place. Because of that the eighth line is coherent with the seventh line. Maghrib is the time of sunset; while "tempat peraduan" is the place of rest. So, the seventh and eight lines mean the movement of the moon that will set.

The next stanza, which consists of two lines "Hati yang masygul menjadi senang" (Sad feeling becomes happy) and "Sukma riang terbang melayang" (Happy feeling flies) shows sad feelings that turn into happiness.

The eleventh line, "Karena lahir Kerinduan semalam" (Because longing came last night) is coherent with the previous line. The word "Karena" (Because) is a mark of the cause of changes in feelings. Longing means the desire and hope to meet. So, this line means that there is a desire and hope to meet the night before.

The word "Ribaan" in the twelfth line, "Ribaan Hua yang kukenang”, means lap; whereas "Hua" stands for Jehovah (God). So, this line means that God's lap is remembered. The last two lines "Kudapat t'rang, kasih dan sayang" and "Serta damai hati di dalam" can be interpreted that the poet feels enlightenment and affection, and peace in heart.

Overall, heuristic reading of the poem shows the atmosphere of a quiet night. The sky is so bright that it shows thousands of sparkling stars and the moon that shines brightly. The wind blows softly. As the moon sets slowly, the poet feels a change of feeling from sadness to happiness because of a longing feeling. A longing to God makes the poet's heart full of love and peace.

\section{- Retroactive Reading}

Retroactive reading is intended to get the full meaning of the poem Bulan Terang. The bright moon can refer to the full moon. The first line implies the silence felt by the poet. The word "udara" in the second line can be interpreted as the atmosphere, so that the second line in the poem means a calm atmosphere. The next line implies that in the midst of the silence, the poet sees the beauty of nature by looking at the stars and the moon that shines brightly in the sky. In the fifth and sixth lines, the poet adds the phenomenon of natural beauty that accompanies the poet in the stillness of the night which is a gentle breeze. The word "berbisik" (whispering) is a form of personification. It is used to provide a clearer and more concrete picture of the situation described. The seventh and eighth lines indicate that the moon that had shone brightly finally sank towards its resting place. Like humans, no matter how strong he/she is, no matter how successful he/she is, no matter how popular he/she is, in the end everything will slowly fade with time. No one is able to resist the natural laws and destiny of God. The next stanza implies the happiness 
felt by the poet deeply in heart. The line "Karna lahir Kerinduan semalam" (Because longing came last night) is an explanation of the reason why the poet feels happy. The capital letter $\mathrm{K}$ in the word "Kerinduan" is a form of graphological deviation, which is intended to provide an effect that something is important. It brings a question for the readers, "Who is the object of the poet's longing feeling?"; and a further question "Why is it so important?". The last three lines are the answers to the questions above. The poet feels a longing for God (Hua) that gives divine light and love and peace in heart.

Based on the hermeneutic reading, the poem Bulan Terang is a contemplation of the poet in seeing nature and all its perishable beauty, and only the presence of God in the heart that can give peace. The model in this poem is "Sukma riang terbang melayang" (Happy feeling flies). Apart from the poetic nature, the line shows the deepest feeling of the poet. The happy feeling enters deeply into the soul. The form of the model is equivalent to the lines of the poem Bulan Terang, and it can be expanded into the form of two variants that spread throughout the poem, namely: (1) clear and calm air; and (2) God's lap. The first variant signifies a peaceful atmosphere felt by the poet while enjoying the silence and beauty of the night sky illuminated by the stars and moonlight. The second variant signifies the presence of God in the heart of the poet, and it creates happiness. Hua is the title for God mentioned in the Bible (Mazmur dan Yesaya). The poet feels the true light (divine light) and peace in the heart by always remembering God.

The models and variants above then form the matrix of the poem Bulan Terang. The matrix in this poem shows that worldly beauty is temporary and true happiness will always be presented by remembering God. It brings the significance that by always remembering God, the heart will be peaceful. Like the moon that illuminates the night, the divine light illuminates the heart.

\section{Analysis of J.E. Tatengkeng's Melati}

\section{Melati}

Tempat ini tida' kucari, Bukan olehku tempat dipilih, Melainkan Tuhan sudah gemari, Saya berkembang di tempat geli!

Hatiku sungguh riang senang, Dalam tempat yang la berikan, Di sini saya pancarkan terang, Seperti la sudah tentukan.

(Tatengkeng, 1974)

\section{- Heuristic Reading}

The poem above is entitled Melati (Jasmine), which has the Latin name Jasminum sambac. It is a flower with white color and smells very fragrant.

In the first stanza, the first line "Tempat ini tida' kucari" (this place I don't search) and the second line "Bukan olehku tempat dipilih" (Not by me the place was chosen) show that the flowers grow in one 
place because of destiny. They never look for or choose their place. This is supported by the next line "Melainkan Tuhan sudah gemari" (But God likes) which means that the place where jasmine is growing is already determined by the God. The word "Geli" in the line "Saya berkembang di tempat geli!" shows a discomfort feeling, sore, or pain. The line means that the jasmine survives even though it grows in an uncomfortable place. The exclamation mark at the end of the fourth line gives confirmation of the inconvenience of the place.

In the second stanza, there is the word "Ia" with a capital letter in the second line "Dalam tempat yang la berikan" (In the place $\mathrm{He} /$ She gave) and the fourth line "Seperti la sudah tentukan" (As He/She has already determined). The word "Ia" is the same as "he/she" which means the third person singular, either male or female. However, the use of the capital letter shows that the word "Ia" refers to God. Therefore, the lines "Hatiku sungguh riang senang" (My heart is very happy) and "Dalam tempat yang la berikan" (In the place the God has given) can be interpreted as expression of joyful feeling towards the place given by the God. The next lines, "Di sini saya pancarkan terang" (Here I emit the brightness) and "Seperti la sudah tentukan" (As the God has determined) show that the jasmine flowers still give beauty and fragrance as God has destined wherever they grow.

\section{- Retroactive Reading}

The title Melati may have a double meaning. First, this title can mean jasmine flowers. Second, because flowers, especially jasmine, are often identified with women, and are often used as names for girls, the word "Melati" in the title of the poem can be considered a metaphor for women.

The first and second lines indicate a woman who is in a situation that she does not want and does not expect. The next two lines imply a woman who is still struggling in the midst of uncomfortable situations because she thinks it is the God's destiny.

In the second stanza, the lines "Hatiku sungguh riang senang" (My heart is very happy) and "Dalam tempat yang la berikan" (In the place the God has given) indicate that the female character is able to feel happy in a situation that had been previously considered uncomfortable. This is supported by the next lines, "Di sini saya pancarkan terang" (Here I emit the brightness) and "Seperti la sudah tentukan" (As the God has determined). The lines imply that the woman is able to be useful and provide benefits to others as determined by The God.

If we interpret jasmine as a female metaphor, then this poem illustrates how women are often in unwanted choices and unpleasant situations. Often, we see and hear how women have to choose between domestic life or a career outside the home, between family and education, and many 
others. But whatever choices they make, when they try and give everything away to the God, they can still be useful in every decision they make.

Based on this retroactive reading, there is an oppositional pair, which is fighting-surrender. Fighting in this context is transformed in the first stanza; while surrender is transformed in the second stanza.

There are two monumental signs in the poem Melati, they are "Saya berkembang di tempat geli!" (I grow in an uncomfortable place) and "Di sini saya pancarkan terang" (Here l emit the brightness). The two lines are two sides of the same matrix, which shows the significance that human beings will not be able to resist destiny, both good and bad. This matrix is rooted in a religious and philosophical discourse that still exists today.

\section{Analysis of Robert Frost's Nothing Gold Can Stay}

\section{Nothing Gold Can Stay}

Nature's first green is gold, Her hardest hue to hold. Her early leaf's a flower; But only so an hour. Then leaf subsides to leaf, So Eden sank to grief, So dawn goes down to day Nothing gold can stay

(Poetry Foundation, 2021)

\section{- Heuristic Reading}

From the beginning, it is difficult to interpret this poem by using linguistic knowledge only. The title of the poem is
Nothing Gold Can Stay. The word "gold" is used in the title as a subject which is then followed by the verb phrase "can stay". It does not give meaning at all.

Furthermore, most of the subsequent sentences do not provide meaningful clues. The first two sentences (lines 1-2) are as follows:

Nature's first green is gold, Her hardest hue to hold.

The first oddity appears in the word "green". Information that can be obtained from the poem is only that "green" belongs to "nature" , and that this "green" is gold. It is difficult to imagine what is meant by "green" colored "gold". The next sentence (lines 3-4) is:

Her early leaf's a flower; But only so an hour.

Some questions arise again. What is meant by "leaf" here? How does this "leaf" have a flower? Why does the ownership of the leaves for flowers only last for approximately one hour?

The last sentence appears in lines $5-8$ as follows:

Then leaf subsides to leaf, So Eden sank to grief, So dawn goes down to day Nothing gold can stay 
This sentence structure consists of three clauses as follows:

Clause 1: Then leaf subsides to leaf

Clause 2: Eden sank to grief

Clause 3: Dawn goes down to day Nothing gold can stay

The existence of the word "so" among clauses shows a causal relationship between these clauses. However, there is no clue that shows how the leaves that cover each other cause heaven to sink into sadness, and dawn to disappear and become a day where nothing cannot be maintained by gold.

It can be said that heuristic reading of the poem cannot give acceptable grammatical meaning. Therefore, it is important to read retroactively.

\section{- Retroactive Reading}

After making repeated readings accompanied by contemplation, the writers finally found a clause as the beginning of the author's interpretation of this poem. The clause is "Then leaf subsides to leaf". This clause reminds the writers of the story of Adam and Eve when they were tempted by a demon whisper persuading them to eat the fruit from the tree of knowledge, which was actually prohibited. There is a possibility that this poem is a picture of the story of Adam and Eve. For this reason, the writers read the poem again from the first line to the last line. Some words were replaced with what were expected to be the interpretations as can be seen in the following table.

\begin{tabular}{|c|c|c|}
\hline WORD & OBJECT & INTERPRETATION \\
\hline Nature & nature & nature \\
\hline first green & first green & first natural environment (heaven) \\
\hline Gold & Gold & gold color \\
\hline early leaf & early leaf & first man (Adam) \\
\hline Flower & flower & first human partner (Eve) \\
\hline an hour & an hour & A moment \\
\hline leaf subsides to leaf & leaf subsides to leaf & leaves close each other \\
\hline dawn goes down & dawn goes down & the decline of Adam and Eve \\
\hline Day & Day & to the world \\
\hline nothing gold can stay & nothing gold can stay & $\begin{array}{l}\text { nothing else can be awaited by the first natural } \\
\text { environment (heaven) }\end{array}$ \\
\hline
\end{tabular}

After that, the writers began to interpret each clause by using the interpretant found. The results of the interpretation of each clause produced interrelated meanings which finally formed a text similar to the story of Adam and Eve. This similarity can be seen in the following table: 


\begin{tabular}{|c|c|c|}
\hline CLAUSES IN POETRY & THE MEANING OF LANGUAGES & THE MEANING OF SEMIOTICS \\
\hline Nature's first green is gold, & $\begin{array}{l}\text { The first natural green color is } \\
\text { gold, }\end{array}$ & Heaven is golden, \\
\hline Her hardest hue to hold. & $\begin{array}{l}\text { The natural color shades are the } \\
\text { hardest to hold. }\end{array}$ & $\begin{array}{l}\text { The color shades are the most } \\
\text { difficult to maintain. }\end{array}$ \\
\hline Her early leaf's a flower; & $\begin{array}{l}\text { The first leaf of nature has a } \\
\text { flower; }\end{array}$ & $\begin{array}{l}\text { The previous occupant (Adam) } \\
\text { had a partner (Eve); }\end{array}$ \\
\hline But only so an hour. & But in only about one hour. & But only for a moment. \\
\hline Then leaf subsides to leaf, & Then the leaves cover the leaves, & $\begin{array}{l}\text { So they then covered the body } \\
\text { with leaves, }\end{array}$ \\
\hline So Eden sank to grief, & So that heaven sinks in sorrow, & So that Heaven sank into grief, \\
\hline So dawn goes down to day & $\begin{array}{l}\text { So that dawn disappears and } \\
\text { becomes afternoon }\end{array}$ & $\begin{array}{l}\text { So that Adam and Eve } \\
\text { descended to earth. }\end{array}$ \\
\hline Nothing gold can stay & $\begin{array}{l}\text { Nothing can be maintained by } \\
\text { gold }\end{array}$ & $\begin{array}{l}\text { Nothing else can be maintained } \\
\text { by heaven. }\end{array}$ \\
\hline
\end{tabular}

The story of Adam and Eve is an actual hypogram (text other than poem analyzed) which basically can be abstracted into two matrices, imperfection and impermanence. These matrices lead to the significance that from the very beginning of its presence on earth, humans are manifestations of imperfectness and mortality.

\section{Analysis of Robert Frost's Fireflies in the Garden}

\section{Fireflies in the Garden}

Here come real stars to fill the upper skies, And here on earth come emulating flies, That though they never equal stars in size, (And they were never really stars at heart) Achieve at times a very star-like start. Only, of course, they can't sustain the part

(Poetry Foundation, 2021)

\section{- Heuristic Reading}

This poem describes the stars that fill the sky, while on earth a number of fireflies appear and they look similar to the stars. The number of fireflies has never matched the number of stars, and these fireflies have never been truly stars. However, the appearance of fireflies sometimes looks similar to stars, except that firefly cannot maintain their abilities.

\section{- Retroactive Reading}

After understanding the meaning of each word in the poem literally, the next steps were to see each word as a sign, and look for patterns and meanings hidden behind the sign. First of all, with a general reading from the first line, up to the last line, we can find a contrasting pattern that stands out in this poem, as can be summarized in the following table: 


\begin{tabular}{|c|c|c|c|c|}
\hline $\begin{array}{l}\text { Line } \\
\text { Number }\end{array}$ & REAL STARS & $\begin{array}{l}\text { Line } \\
\text { Number }\end{array}$ & EMULATING FLIES & CONTRAST \\
\hline \multirow{5}{*}{1} & \multirow{5}{*}{$\begin{array}{l}\text { Here come } \\
\text { real stars to } \\
\text { fill the upper } \\
\text { skies, }\end{array}$} & 2 & $\begin{array}{l}\text { And here on earth } \\
\text { come emulating } \\
\text { flies, }\end{array}$ & $\begin{array}{l}\text { Real Stars } \\
\text { vs } \\
\text { Emulating Flies imitating } \\
\text { Skv vs Earth }\end{array}$ \\
\hline & & 3 & $\begin{array}{l}\text { That though they } \\
\text { never equal stars in } \\
\text { size, }\end{array}$ & $\begin{array}{l}\text { Sky vs Earth } \\
\text { Fill the Sky } \\
\text { (A lot) } \\
\text { vs } \\
\text { Emulating flies cannot equal a } \\
\text { number of stars }\end{array}$ \\
\hline & & 4 & $\begin{array}{l}\text { (And they were } \\
\text { never really stars at } \\
\text { heart) }\end{array}$ & $\begin{array}{l}\text { Real Stars } \\
\text { vs } \\
\text { Not Real Stars }\end{array}$ \\
\hline & & 5 & $\begin{array}{l}\text { Achieve at times a } \\
\text { very star-like start. }\end{array}$ & $\begin{array}{l}\text { Real Stars } \\
\text { vs } \\
\text { Early like stars }\end{array}$ \\
\hline & & 6 & $\begin{array}{l}\text { Only, of course, they } \\
\text { can't sustain the } \\
\text { part. }\end{array}$ & $\begin{array}{l}\text { Real Stars } \\
\text { vs } \\
\text { unable to maintain the ability }\end{array}$ \\
\hline
\end{tabular}

It is clear in this table that basically the things contrasted in this poem are the real stars and the fireflies. The next question is what is meant by the real stars, and what is meant by fireflies? In the table above, it can be seen that real stars are in the sky and there are so many of them, and this gives a similarity to the basic meaning of perfection. On the other hand, fireflies are described as being on earth (under the sky), imitating stars, not as many as stars, not real stars, and unable to maintain their abilities. This leads us to one core meaning, imperfection. Thus stars have perfection, while fireflies do not. If we interpret stars as the God, and fireflies as humans, then we can deduce two hypograms, namely Perfection belongs to God and Imperfection to human nature. The matrix that can be drawn from these two contrasting hypograms is "surrender". The matrix further leads us to a significance / meaning that the essence of human life is when it can surrender to the God, the Most Perfect.

\section{Analysis of Robert Frost's After Apple Picking}

\section{After Apple-Picking}

1. My long two-pointed ladder's sticking through a tree

2. Toward heaven still,

3. And there's a barrel that I didn't fill

4. Beside it, and there may be two or three

5. Apples I didn't pick upon some bough.

6. But I am done with apple-picking now.

7. Essence of winter sleep is on the night,

8. The scent of apples: I am drowsing off.

9. I cannot rub the strangeness from my sight

10. I got from looking through a pane of glass

11. I skimmed this morning from the drinking trough 
12. And held against the world of hoary grass.

13. It melted, and I let it fall and break.

14. But I was well

15. Upon my way to sleep before it fell,

16. And I could tell

17. What form my dreaming was about to take.

18. Magnified apples appear and disappear,

19. Stem end and blossom end,

20. And every fleck of russet showing clear.

21. My instep arch not only keeps the ache,

22. It keeps the pressure of a ladder-round.

23. I feel the ladder sway as the boughs bend.

24. And I keep hearing from the cellar bin

25. The rumbling sound

26. Of load on load of apples coming in.

27. For I have had too much

28. Of apple-picking: I am overtired

29. Of the great harvest I myself desired.
30. There were ten thousand fruit to touch,

31. Cherish in hand, lift down, and not let fall.

32. For all

33. That struck the earth,

34. No matter if not bruised or spiked with stubble,

35. Went surely to the cider-apple heap

36. As of no worth.

37. One can see what will trouble

38. This sleep of mine, whatever sleep it is.

39. Were he not gone,

40. The woodchuck could say whether it's like his

41. Long sleep, as I describe its coming on,

42. Or just some human sleep.

(Poetry Foundation, 2021)

This poem has 42 lines, but there are only 14 sentences as appear in the following table:

\begin{tabular}{ccl}
$\begin{array}{c}\text { Line } \\
\text { Number }\end{array}$ & $\begin{array}{c}\text { Sentence } \\
\text { Number }\end{array}$ & \multicolumn{1}{c}{ Sentences } \\
\hline $1-5$ & 1 & $\begin{array}{l}\text { My long two-pointed ladder's sticking through a tree toward heaven } \\
\text { still, and there's a barrel that I didn't fill beside it, and there may be two or } \\
\text { three Apples I didn't pick up on some bough. }\end{array}$ \\
\hline 6 & 2 & But I am done with apple-picking now. \\
\hline $7-8$ & 3 & $\begin{array}{l}\text { Essence of winter sleep is on the night, the scent of apples: I am drowsing } \\
\text { off. }\end{array}$ \\
\hline $13-12$ & 4 & $\begin{array}{l}\text { I cannot rub the strangeness from my sight I got from looking through a } \\
\text { pane of glass I skimmed this morning from the drinking trough and held } \\
\text { against the world of hoary grass. }\end{array}$ \\
\hline $14-17$ & 5 & $\begin{array}{l}\text { It melted, and I let it fall and break. } \\
\text { But I was well upon my way to sleep before it fell, and I could tell what form } \\
\text { my dreaming was about to take. }\end{array}$ \\
\hline $18-20$ & 7 & $\begin{array}{l}\text { Magnified apples appear and disappear, stem end and blossom end, and } \\
\text { every fleck of russet showing clear. }\end{array}$ \\
\hline $21-22$ & 8 & $\begin{array}{l}\text { My instep arch not only keeps the ache, it keeps the pressure of a ladder- } \\
\text { round. }\end{array}$ \\
\hline 23 & 9 & $\begin{array}{l}\text { Ifeel the ladder sway as the boughs bend. } \\
\text { And I keep hearing from the cellar bin the rumbling sound of load on load of } \\
\text { apples coming in. }\end{array}$ \\
\hline
\end{tabular}




\begin{tabular}{ccl}
$\begin{array}{c}\text { Line } \\
\text { Number }\end{array}$ & $\begin{array}{c}\text { Sentence } \\
\text { Number }\end{array}$ & \multicolumn{1}{c}{ Sentences } \\
\hline $27-29$ & 11 & $\begin{array}{l}\text { For I have had too much of apple-picking: I am overtired of the great } \\
\text { harvest I myself desired. }\end{array}$ \\
\hline $30-31$ & 12 & $\begin{array}{l}\text { There were ten thousand fruit to touch, cherish in hand, lift down, and not } \\
\text { let fall. }\end{array}$ \\
\hline $32-36$ & 13 & $\begin{array}{l}\text { For all that struck the earth, no matter if not bruised or spiked with } \\
\text { stubble, went surely to the cider-apple heap as of no worth. }\end{array}$ \\
\hline $37-38$ & 14 & $\begin{array}{l}\text { One can see what will trouble this sleep of mine, whatever sleep it is. } \\
\text { Were he not gone, the woodchuck could say whether it's like his long sleep, } \\
\text { as I describe its coming on, or just some human sleep. }\end{array}$ \\
\hline
\end{tabular}

\section{- Heuristic Reading}

Heuristic reading of this poem gives the impression that this poem is nothing more than a story about an apple picker. Words such as trees, apples, bough, and apple-picking give an index that the setting of the story is an apple orchard; while the explicit setting can be seen from the "Essence of winter sleep is on the night" clause in sentence 3 .

At the beginning of the poem, the "I" character in the poem sees that the ladders used to pick apples are still leaning underneath the tree, and there is still one empty barrel that had not been filled, while in the tree branches there are still a few apples that had not been picked. However, the "I" character thinks that his/her job is finished. Furthermore, the "I" feels sleepy and in a half-awake state, the "I" experiences a strange memory with a piece of glass. The "I" then falls asleep and dreams of picking apples, until finally feeling exhausted because a lot of apples have to be picked. At the end of the poem, the "I" thinks that the weirdness of the dreams he/she feels can occur in three types of sleep, namely sleeping forever (dying), sleeping temporarily (for example in a coma), and sleeping normally.

At first glance it seems that there is nothing special about the story of someone who dreams while sleeping. However, some "oddities" are found in this poem. The first oddity can be felt with the memory of a piece of glass that was found by the "I" in an animal drinking place. What is special about this piece of glass? This oddity is getting bigger because by looking at that piece of glass, the "I" already knows what he/she will see in his/her dream: "But I was well upon my way to sleep before it fell, and I could tell what I was dreaming about to take" (sentence 6). Another oddity is the idea of the "I" who divides sleep over three types. These peculiarities indicate that this text is not an ordinary story, but is a poem that basically conveys an implied meaning. 


\section{- Retroactive Reading}

A more careful implementation of retroactive reading was very helpful in finding the interpreter of this poem. The length of the poem was a challenge in making a comprehensive interpretation, so to facilitate the analysis, the writers first tried to find the parts in the "story" of the poem as can be seen in the following table:

\begin{tabular}{|c|c|c|c|}
\hline $\begin{array}{l}\text { Line } \\
\text { Number }\end{array}$ & $\begin{array}{l}\text { Sentence } \\
\text { Number }\end{array}$ & Sentence & \multirow{3}{*}{$\begin{array}{l}\text { Introductory Stage } \\
\text { - Background Scene: Apple } \\
\text { Garden } \\
\text { - Time Setting: The end of the } \\
\text { harvest season, Entering the } \\
\text { winter } \\
\text { - Initial Condition: there are still } \\
\text { some apples that have not } \\
\text { been picked, but the "I" does } \\
\text { not want to continue working. }\end{array}$} \\
\hline $1-5$ & 1 & $\begin{array}{l}\text { My long two-pointed ladder's sticking } \\
\text { through a tree toward heaven } \\
\text { still, and there's a barrel that I didn't } \\
\text { fill beside it, and there may be two or } \\
\text { three Apples I didn't pick upon some } \\
\text { bough. }\end{array}$ & \\
\hline 6 & 2 & But I am done with apple-picking now. & \\
\hline $7-8$ & 3 & $\begin{array}{l}\text { Essence of winter sleep is on the } \\
\text { night, the scent of apples: I am } \\
\text { drowsing off. }\end{array}$ & \multirow{8}{*}{$\begin{array}{l}\text { Stage of the Problem } \\
\text { - Event 1: The "I" character is } \\
\text { sleepy } \\
\text { - Event2: In the midst of falling } \\
\text { asleep, the "I" experiences a } \\
\text { strange incident with a piece of } \\
\text { glass. } \\
\text { - Event 3: While sleeping, the "I" } \\
\text { experiences a weird dream } \\
\text { about a piece of glass (Glass = } \\
\text { Reflection = ICON) } \\
\text { - Event 4: while being half } \\
\text { asleep, the "I" character } \\
\text { dreams of his/her activity when } \\
\text { picking apples (flashback). } \\
\text { Activities that are not easy } \\
\text { because they are full of } \\
\text { challenges (pain when climbing } \\
\text { a swaying ladder to reach the } \\
\text { fruit by arching a branch). This } \\
\text { activity must be also done with } \\
\text { due care, because the fallen } \\
\text { fruit will be considered } \\
\text { worthless, and will only be } \\
\text { made into apple drinks. }\end{array}$} \\
\hline $9-12$ & 4 & $\begin{array}{l}\text { I cannot rub the strangeness from my } \\
\text { sight I got from looking through a } \\
\text { pane of glass I skimmed this morning } \\
\text { from the drinking trough and held } \\
\text { against the world of hoary grass. }\end{array}$ & \\
\hline 13 & 5 & It melted, and I let it fall and break. & \\
\hline $14-17$ & 6 & $\begin{array}{l}\text { But I was well upon my way to sleep } \\
\text { before it fell, and I could tell what } \\
\text { form my dreaming was about to take. }\end{array}$ & \\
\hline $18-20$ & 7 & $\begin{array}{l}\text { Magnified apples appear and } \\
\text { disappear, stem end and blossom } \\
\text { end, and every fleck of russet showing } \\
\text { clear. }\end{array}$ & \\
\hline $21-22$ & 8 & $\begin{array}{l}\text { My instep arch not only keeps the } \\
\text { ache, it keeps the pressure of a ladder- } \\
\text { round. }\end{array}$ & \\
\hline 23 & 9 & $\begin{array}{l}\text { I feel the ladder sway as the boughs } \\
\text { bend. }\end{array}$ & \\
\hline $24-26$ & 10 & $\begin{array}{l}\text { And I keep hearing from the cellar bin } \\
\text { the rumbling sound of load on load of } \\
\text { apples coming in. }\end{array}$ & \\
\hline
\end{tabular}




\begin{tabular}{|c|c|c|c|}
\hline $\begin{array}{l}\text { Line } \\
\text { Number }\end{array}$ & $\begin{array}{l}\text { Sentence } \\
\text { Number }\end{array}$ & Sentence & Storyline in Poem \\
\hline $27-29$ & 11 & $\begin{array}{l}\text { For I have had too much of apple- } \\
\text { picking: I am overtired of the great } \\
\text { harvest I myself desired. }\end{array}$ & \multirow{3}{*}{$\begin{array}{l}\text { Peak Phase Problem } \\
\text { The "I" character experiences } \\
\text { fatigue because of the harvesting } \\
\text { activities that have indeed } \\
\text { become his/her biggest wishes. }\end{array}$} \\
\hline $30-31$ & 12 & $\begin{array}{l}\text { There were ten thousand fruit to } \\
\text { touch, cherish in hand, lift down, and } \\
\text { not let fall. }\end{array}$ & \\
\hline $32-36$ & 13 & $\begin{array}{l}\text { For all that struck the earth, no matter } \\
\text { if not bruised or spiked with } \\
\text { stubble, went surely to the cider-apple } \\
\text { heap as of no worth. }\end{array}$ & \\
\hline $37-38$ & 14 & $\begin{array}{l}\text { One can see what will trouble this } \\
\text { sleep of mine, whatever sleep it is. }\end{array}$ & \multirow{2}{*}{$\begin{array}{l}\text { Reflection Stage } \\
\text { This strange event will disturb all } \\
\text { types of "sleep, including } \\
\text { "sleeping forever ", sleeping for a } \\
\text { long time (such as a coma), or a } \\
\text { temporary sleep. }\end{array}$} \\
\hline $39-42$ & 15 & $\begin{array}{l}\text { Were he not gone, the woodchuck } \\
\text { could say whether it's like his long } \\
\text { sleep, as I describe its coming on, or } \\
\text { just some human sleep. }\end{array}$ & \\
\hline
\end{tabular}

The depictions and events in the poem can be grouped into four stages, which can be interpreted as follows:

- The first stage is the condition in which the "I" character chooses to stop picking apples, even though this work is not yet completed, which is indicated by the presence of an empty barrel and several apples still hanging on the tree branches. This stage can be interpreted as a condition of someone who has reached a saturation point in life.

- After stopping his/her work, the "I" character experiences drowsiness and then falls asleep and dreams. Therefore, it can be interpreted as the second stage where a person feels tired after reaching the peak of success in his life, which in this poem is described by the number of apples picked: ". . load on load of apples coming in (line 33). These sleeping and dreaming events become a flashback, which can be interpreted as old people who always remember or are reminded of their actions in their youth.

- The third event becomes the culmination of the story depicted in the sentence "I am overtired of the great harvest I myself desired". This can be interpreted as a time when someone is no longer able to work (no longer productive)

- The last stage is the stage of reflection where the "I" character says that the dream that he/she experiences can occur in three types of sleep: temporary sleep, long sleep (for example at coma), or sleeping forever (death). The interpretation that can be found is that people's actions when they are young will always be something to remember, even when someone has died and is buried. There is a message here for readers to always be careful in life. Good 
deeds will be remembered as achievements, but bad deeds will always haunt until someone is in the grave.

These four stages become potential hypograms (connotations) which can be abstracted into one matrix, namely the end of human life. This matrix brings the reader to a significance / meaning of the poem, which is to be careful in behaving in life, because later that behavior will be a good memory (if good behavior) or otherwise regretted until the end of life, even when humans have died.

\section{CONCLUSIONS AND SUGGESTIONS}

The analysis has revealed matrices and significance of J. E Tatengkeng and Robert Frost's poems. The poets' works similarly reflect the value of love, beauty of nature, and religious belief.

Furthermore, it can be concluded that the Semiotic model of Riffaterre is very helpful in extracting the meaning hidden in a poem. The model can be successfully applied on poetic language that is originally "difficult" due to its heavy load of connotative meaning. However, further research is needed to find out whether the model can be used with poems that have more contemporary characteristics.

\section{REFERENCES}

Adudu, H. H. \& Husain, D. (2014). Semiotic Analysis in William Blake Poems. BRITISH, Jurnal Bahasa dan Sastra Inggris, 1(1), 3955. Retrieved October 16, 2021, from https://journal.umgo.ac.id/index.php/Briti sh/article/view/336
Bahador, R. \& Lashkarian, A. (2014). Riffaterre's Semiotics of Poetry in Re- Reading John Keats' "Bright Star" and Sepehri's "To the Garden of Co-Travelers". Asian Journal of Multidisciplinary Studies, 2(9), 116-122. Retrieved October 17, 2021, from https://paperzz.com/download/8846878

Choirini, M. \& Nursida, I. (2020). Unveil the Meaning of Ibn Al-Farid's Sufistic Poetry Using the Riffaterre's Semiotics. Arabiyat: Jurnal Pendidikan Bahasa Arab dan Kebahasaaraban, 7(2), 235-250. Retrieved October 16, 2021, from http://journal.uinjkt.ac.id/index.php/arabi yat/article/view/18115

Lantowa, J., Marahayu, N.M., \& Khairussibyan, M. (2017). Semiotika: Teori, Metode, dan Penerapannya dalam Penelitian Sastra. Yogyakarta: Deepublish. Retrieved October 17, 2021, from https://www.google.co.id/books/edition/ Semiotika_Teori_Metode_dan_Penerapan nya/i1xDDwAAQBAJ?hl=en \&gbpv $=1 \& \mathrm{dq}=\mathrm{L}$ antowa+Semiotika:+Teori,+Metode,+dan+ Penerapannya+dalam+Penelitian+Sastra.\& printsec=frontcover

Peirce, C. S., \& In Buchler, J. (1955). Philosophical Writings of Peirce. New York: Dover Publications. Retrieved October 17, 2021, from https://cdchester.co.uk/wpcontent/uploads/2018/05/PhilosophicalWritings-of-Peirce-Charles-S.-PeirceJustus-Buchler-ed..pdf

Poetry Foundation. (2021). Retrieved October 18, 2021, from https://www.poetryfoundation.org/poets/ robert-frost\#tab-poems

Pradopo, R. D. (2007). Beberapa Teori Sastra, Metode Kritik, dan Penerapannya. Yogyakarta: Pustaka Pelajar.

Ratih, R. (2016). Teori dan Aplikasi Semiotik 
Michael Riffaterre. Yogyakarta: Pustaka Pelajar.

Setiawan, E. P., Andayani, \& Winarni, R. (2017). The Meaning and Teaching of "Budi Pekerti" in the Poetry of Kekean by F. Aziz Manna: Semiotic Studies of Riffaterre. Humanus, Jurnal IImiah IImu-IImu Humaniora, 16(2), 190-200. Retrieved October 16, 2021, from http://ejournal.unp.ac.id/index.php/huma nus/article/view/8034

Sipahutar, R. \& Arianto, T. (2019). An Analysis of Semiotic Riffaterre in Walt Whitman Selected Poem, Journal BASIS, 6(2), 237248. Retrieved October 16, 2021, from https://doi.org/10.33884/basisupb.v6i2.1 428
Sugiyo \& Nurmila, S. (2020). Riffaterre's Semiotic Study on Elegi by Joko Pinurbo, AKSIS, Jurnal Pendidikan Bahasa dan Sastra Indonesia, 4(2), 401-409. Retrieved October 16, 2021, from http://journal.unj.ac.id/unj/index.php/aksi s/article/view/16608

Tatengkeng, J. E. (1974). Rindu Dendam. Jakarta: Pustaka Jaya.

Viensen, M. (2020). An Analysis of Symbolic Signs in John Milton's Poems: Semiotic Approach. Unpublished Undergraduate Thesis, Universitas Putera Batam, Batam. Retrieved October 16, 2021, from http://repository.upbatam.ac.id/445/

Zoest, A. van. (1990), Fiksi dan Nonfiksi dalam Kajian Semiotik. Jakarta: Intermasa. 